\title{
Immunocytochemical localization of AMPA selective glutamate receptor subunits in the rat cochlea
}

\author{
Hiromichi Kuriyama, Oliver Jenkins, Richard A. Altschuler * \\ Kresge Hearing Research Institute. Department of Otolaryngology, University of Michigan, 1301 East Ann Street Ann Arbor, MI. 48109-0506 USA
}

Received 19 December 1994; revised 1 August 1994; accepted 14 August 1994

\begin{abstract}
The localization of subunits of the $\alpha$-amino-3-hydroxy-5-methyl-4-isoxazole propionic acid (AMPA) selective glutamate receptor, termed Glutamate receptor (GluR) was examined in the rat cochlea using affinity purified polyclonal antibody to GluR subunits (GluR 1-4). GluR 2/3 and GluR 4 immunoreactive (IR) staining was observed in rat spiral ganglion cells, while GluR 1 IR was not. GluR 4 IR staining was also seen in puncta at inner and outer hair cell bases. These results suggest that GluR $2 / 3$ and GluR 4 are components of excitatory amino acid synapses in the rat cochlea.
\end{abstract}

Keywords: Fxcitatory amino acid; AMPA receptor; Cochlea; Hair cell; Immunocytochemistry

\section{Introduction}

There is now much evidence suggesting that glutamate or a related excitatory amino acid (EAA) is the transmitter of cochlear hair cells, including microchemical localizations of glutamate and aspartate in the organ of Corti (Godfrey et al., 1976), release studies (Bledsoe et al., 1981; Drescher and Drescher, 1985; Jenison and Bobbin, 1985), post synaptic action on the auditory nerve (Bobbin and Thompson, 1978; Bobbin, 1979; Littman et al., 1989; Comis and Leng, 1979; Klinke and Oertel, 1977; Puel et al., 1989; Puel et al., 1991), immunocytochemical localizations (Altschuler et al., 1989; Eybalin and Altschuler, 1990), and uptake studies (Eybalin and Pujol, 1983; Gulley et al., 1979; Ryan and Schwartz, 1984, Schwartz and Ryan, 1986). There is also considerable evidence that the hair cell transmitter acts on an EAA receptor, including pharmacological studics (Bledsoe et al., 1981; Bledsoe et al., 1988 for review; Bobbin et al., 1981; Bobbin and Ceasar, 1987; Jenison and Bobbin, 1985; Jenison et al., 1986; Kusakari et al., 1984; Nakagawa et al., 1991) and excitotoxicity studies (Janssen et al., 1991; Juiz et al.,

\footnotetext{
* Corresponding author. Fax: (313) 764-0014.
}

1989; Puel et al., 1991; Pujol et al., 1985). Recent advances in molecular biology have made further analysis of the EAA receptor possible. A family of EAA receptors, termed Glutamate Receptors (GluR) was cloned (Hollmann et al., 1989; Keinanen et al., 1990; Boulter et al., 1990). The GluR family is composed of several subunits which can combine to form hetcromeric complexcs. Different combinations of subunits and sub-types can result in different physiological properties (e.g. Boulter et al., 1990, Hollmann et al., 1991). Different expressions of the GluR have been seen in different regions of the brain. It is, therefore, important to know which GluR subunits are present in inner and outer hair cell synapses. GluR 1-4 correspond to what has been called the $\alpha$-amino-3-hydroxy5-methyl-4-isoxazole propionic acid (AMPA) receptor based on pharmacological studies. Antibodies have been raised to synthetic peptides corresponding to carboxy terminal sequences of these four different subunits (GluR 1-4) (Wenthold et al., 1990, Wenthold et al., 1992, Petralia and Wenthold, 1992). Three affinity purified antibodies (the kind gift of Dr. Robert Wenthold); two specific for GluR 1 and GluR 4 respectively, another that recognized both GluR 2 and GluR 3 but could not differentiate between them (therefore considered GluR 2/3) were used in immunocytochemical and immunoblot studies of the rat cochlea. 


\section{Materials and methods}

\subsection{Animals}

Thirty Sprague-Dawley rats $(150-200 \mathrm{~g})$ were used in this study. Eighteen rats were used for immunocytochemistry and 12 rats were used for western blot analysis. The care and use of animals reported in this study was approved and supervised by the University of Michigan Unit on Laboratory Animal Medicine.

\subsection{Immunocytochemistry}

Rats were heavily anesthetized with $17.5 \%$ chloral hydrate $(0.2 \mathrm{ml} / 100 \mathrm{gm})$ and perfused intracardially with $0.1 \mathrm{M}$ phosphate buffer (PB), $\mathrm{pH} 7.4$, followed by fixative. In most animals the fixative was $4 \%$ paraformaldehyde in PB. These were evaluated in surface preparations and cryostat sections. In some animals, additional fixatives $(0.5 \%$ paraformaldehyde in $\mathrm{PB} ; 4 \%$ paraformaldehyde and $0.2 \%$ glutaraldehyde in PB; Zamboni fixative $0.2 \%$ picric acid; $4 \%$ paraformaldehyde in PB; and PLP (periodate-lysine-picric acid) fixative by vascular fixation, and $100 \%$ acetone $/ 100 \%$ methanol as a local fixative on dissected unfixed cochlea) were employed to examine the influence of fixative on immunostaining. These were evaluated as surface preparations.

Cochleae were removed from the temporal bone and received intrascalar fixation followed by $2 \mathrm{~h}$ postfixation, with the initial fixative. Cochleae were then micro-dissected for surface preparations as described previously (Altschuler et al., 1985; Fex and Altschuler, 1986) or decalcified with $3 \%$ EDTA $0.1 \mathrm{M} \mathrm{PB}$ at $4^{\circ} \mathrm{C}$ for 3-5 days and then rapidly frozen with liquid nitrogen. Frozen cochleae were sectioned $(15 \mu \mathrm{m})$ at $-20^{\circ} \mathrm{C}$ and thaw-mounted on gelatin-coated slides. Immunoperoxidase and immunofluorescent immunocytochemistry were carried out on both surface preparations and cryostat sections as described previously (Altschuler et al., 1985; Fex and Altschuler, 1986). Pre-incubation of sections or cochleae with $10 \%$ normal goat serum in PBS for $\mathbf{4 0}$ min was followed by application of affinity purificd polyclonal antibodies to GluR1-4 (Petralia and Wenthold, 1992) diluted in PBS with $0.3 \%$ triton $\mathrm{X}-100$. The Vectastain ABC kit (Vector Laboratories, Inc., Burlingame, CA) and fluorescein (FITC) conjugated anti-rabbit IgG (Jackson Immunoresearch Laboratories, Inc., West Grove, PA) were used for detection of primary antibodies. Sections or surface preparations were viewed under bright-field, differential interference, or epifluorescent optics or with a BioRad laser scanning confocal microscope. In the latter case optical sections from different focal planes in a surface preparation could be digitized and combined to provide an overview of staining.

Some cryostat sections were co-labeled, using either antibody to GluR $2 / 3$ or GluR 4 plus a monoclonal antibody to neurofilament $200 \mathrm{kDa}$ (Boehringer Mannheim). The antibody to the $200 \mathrm{kDa}$ subunit predominantly stains type II spiral ganglion cells (Berglund and Ryugo, 1986 Berglund and Ryugo, 1991 Romand et al., 1988 Dau and Wenthold., 1989). Berglund and Ryugo (1986) and Berglund and Ryugo (1991) reported the $200 \mathrm{kDa}$ antibody also stained a small population of type I cells in the hook region of the cochlea, Romand et al. (1988) reported $200 \mathrm{kDa}$ immunostaining of a small sub-population of type I cells in all turns of the rat cochlea, with type I staining considerably lighter than that of type IIs, while Dau and Wenthold, (1989) found the type I sub-population staining as intense as type II staining in guinea pig cochlea.

Sections for double staining were first incubated in antibody to Glutamate receptor overnight at $4^{\circ} \mathrm{C}$ and then in FITC conjugated anti-rabbit IgG (Jackson Immunoresearch Laboratories, Inc., West Grove, PA) for $1 \mathrm{~h}$ at room temperature (RT). After rinsing, sections were again incubated in antibody to neurofilament overnight at $4^{\circ} \mathrm{C}$ and then incubated in Rhodamine conjugated anti-mouse IgG (Jackson Immunoresearch Laboratories, Inc., West Grove, PA) for 1 h at RT.

\subsection{Electrophoresis and western blot}

The animals were deeply anesthetized with intraperitoneal injection of $17.5 \%$ chloral hydrate $(0.2$ $\mathrm{ml} / 100 \mathrm{~g}$ ) and sacrificed by decapitation. Cochlear nucleus and cerebellum were removed from brain and temporal bones were rapidly dissected. Thirty $\mathrm{mg}$ of protein was subjected to SDS-PAGE (3-12\% acrylamide gradients from Jule Inc., New Haven, CT) and were electrophoresed at $40 \mathrm{~mA}$ constant current for 1 h. The separated proteins were electrophoretically transferred to nitrocellulose membrane (Millipore Corp., Bedford, MA) at $100 \mathrm{~mA}$ constant current for 1 h. The blots were treated with Blotto $(5 \%$ dried milk and $0.2 \%$ Tween 20 in $20 \mathrm{mM}$ Tris- $\mathrm{HCl}, 500 \mathrm{mM} \mathrm{NaCl}$ [TBS], $\mathrm{pH} 7.5$ ) for $1 \mathrm{~h}$ at room temperature to block nonspecific binding, and then incubated with GluR $2 / 3$ and GluR 4 antibody diluted 1:100 in Blotto, overnight at $4^{\circ} \mathrm{C}$. After washing with several changes of Blotto, the blots were incubated with biotinylated goat anti-rabbit IgG (Vector Laboratories, Inc., Burlingame, CA) at a dilution of $1: 400$ in Blotto for $1 \mathrm{~h}$ at room temperature, then incubated with an avidin-biotinylated horse radish peroxidase (HRP) complex (Vector Laboratories, Inc.) for $45 \mathrm{~min}$, then rinsed with a 
change of fresh Blotto and two changes of TBS. The bound HRP was detected with substrate 4-chloro-1naphthol by using $30 \mathrm{mg} / 10 \mathrm{ml}$ of methanol, $50 \mathrm{ml}$ of TBS and $165 \mathrm{ml}$ of $30 \%$ hydrogen peroxide as the chromogen.

\section{Results}

\subsection{Immunocytochemistry}

Immunoperoxidase and immunofluorescent techniques showed the same results. GluR 4 immunoreactive staining (IR) was seen in spiral ganglion cells in cryostat sections (Fig. 1A). In cryostat sections and surface preparations, immunostaining could be observed at the bases of inner and outer hair cells (Fig. 2). In surface preparations, multiple labeled puncta, most likely corresponding to afferent terminals, were observed at inner (Fig. 2A, D) and outer hair cell bases (Fig. 2B-D). No major differences were discerned in the pattern of immunolabeled puncta at inner hair cell bases on the modiolar and tunnel sides. There was also a comparable number of puncta at inner hair cell bases in all turns of the cochlear spiral. While multiple puncta were seen at outer hair cell bases in all rows and all turns, this immunolabeling was most prominent in apical turns. Puncta immunolabeled for GluR 4 beneath inner and outer hair cell could also be observed in cryostat sections (Fig. 2C). Often immunolabeled fibers could be seen giving rise to these puncta, providing evidence that they are post-synaptic. In the casc of outer hair cells, these were lower tunnel crossing fibers rising to reach the outer hair cell bases, reinforcing their identification as afferents.

GluR 2/3 IR staining of spiral ganglion cells was observed in cryostat sections (Fig. 1B). Antibody to GluR 2/3, however, did not immunolabel puncta at inner or outer hair cell bases with any of the fixative employed. No immunoreactive labeling was seen in the cochlea with GluR 1 in either cryostat sections or in surface preparations with any fixatives.

\subsection{Co-labeling}

In co-immunostained cryostat sections, GluR $2 / 3$ and GluR 4 IRs were seen in spiral ganglion cells that were both labeled or unlabeled by antibody to neurofilament $200 \mathrm{kDa}$ (Fig. 3). While most spiral ganglion cells with neurofilament immunoreactive staining also showed GluR 2/3 or GluR 4 immunoreactive staining (filled arrowheads, Fig. 3A-D), examples were seen where neurofilament immunopositive cells were not GluR immunoreactive (unfilled arrowhead, Fig. 3C, D), however these were a small percentage (under $25 \%$ ).

\subsection{Western blot analysis}

Immunoblot analysis with antibodies to GluR $2 / 3$ and GluR 4 revealed intense $100 \mathrm{kDa}$ MW bands in cochlear sensorineural epithelium, modiolus including spiral ganglion and auditory nerve, cochlear nucleus and cerebellum. Several less intense bands in each lanes were also seen (Fig 4). No other major bands in the lane for organ of Corti (lane B) were seen for either GluR 2/3 or GluR 4.

\section{Discussion}

We observe GluR 4 IR apposing both inner and outer hair cell bases in all turns of the cochlea spiral and GluR 4 and GluR 2/3 IRs in both type I and type II spiral ganglion cells. These results provide strong evidence that AMPA glutamate receptors are a component of synapses of both inner and outer hair cells with the auditory nerve. The function and activity of the outer hair cell-auditory nerve synapses is still unclear. One might expect differences in the components of the excitatory amino acid receptors apposing inner versus outer hair cells based on studies of excitatory amino acid-induced swelling by Pujol et al., (1985). These demonstrate auditory nerve terminals at inner hair cell bases are more likely to show such swelling. While glutamate IR staining is seen in inner and outer hair cells (Altschuler et al., 1989; Eybalin and Altschuler 1990; Eybalin, 1993), Eybalin (1993) notes that glutamate IR staining is much higher in inner hair cells. Further studies will be necessary to better differentiate receptors at the inner and outer hair cell synapses and the relevance to function. The lack of co-labeling for some type II spiral ganglion cells could suggest a separate population that does not produce GluR. This, however, is more likely due to a lower expression of GluR in type II spiral ganglion cells such that a percentage are below the threshold for visualization with immunocytochemistry. The sub-populationof type I spiral ganglion cells that expresses higher levels of the 200 $\mathrm{kDa}$ neurofilament also co-expresses both GluR 2/3 and GluR4.

We observe GluR 4 immunostaining of both spiral ganglion cells and of puncta at hair cell bases. Initial studies of AMPA receptor expression in the cochlea, using in situ hybridization methods, showed expression of GluR 2 and GluR 3 mRNA in spiral ganglion cells, and did not detect expression of GluR 4 (Ryan et al., 1991). More recent studies using DNA amplification techniques have shown the presence of GluR 1,2,3 and 4 cDNA in cochlea (Doi et al., 1992; Ryan et al., 1993). These suggest that GluR 1 and 4 are produced, but perhaps at lower levels than GluR 2 and 3. The impor- 
tance of differences in relative production still need to be determined, as well as the implications towards synaptic placement and turnover. Safieddine and Eybalin showed GluR4 mRNA expression in satellite glials cells in Rosenthals canal, however we did not see immunocytochemical localization in these cells. It is possible that there is a post-translational modification in these cells that changes antigenicity.
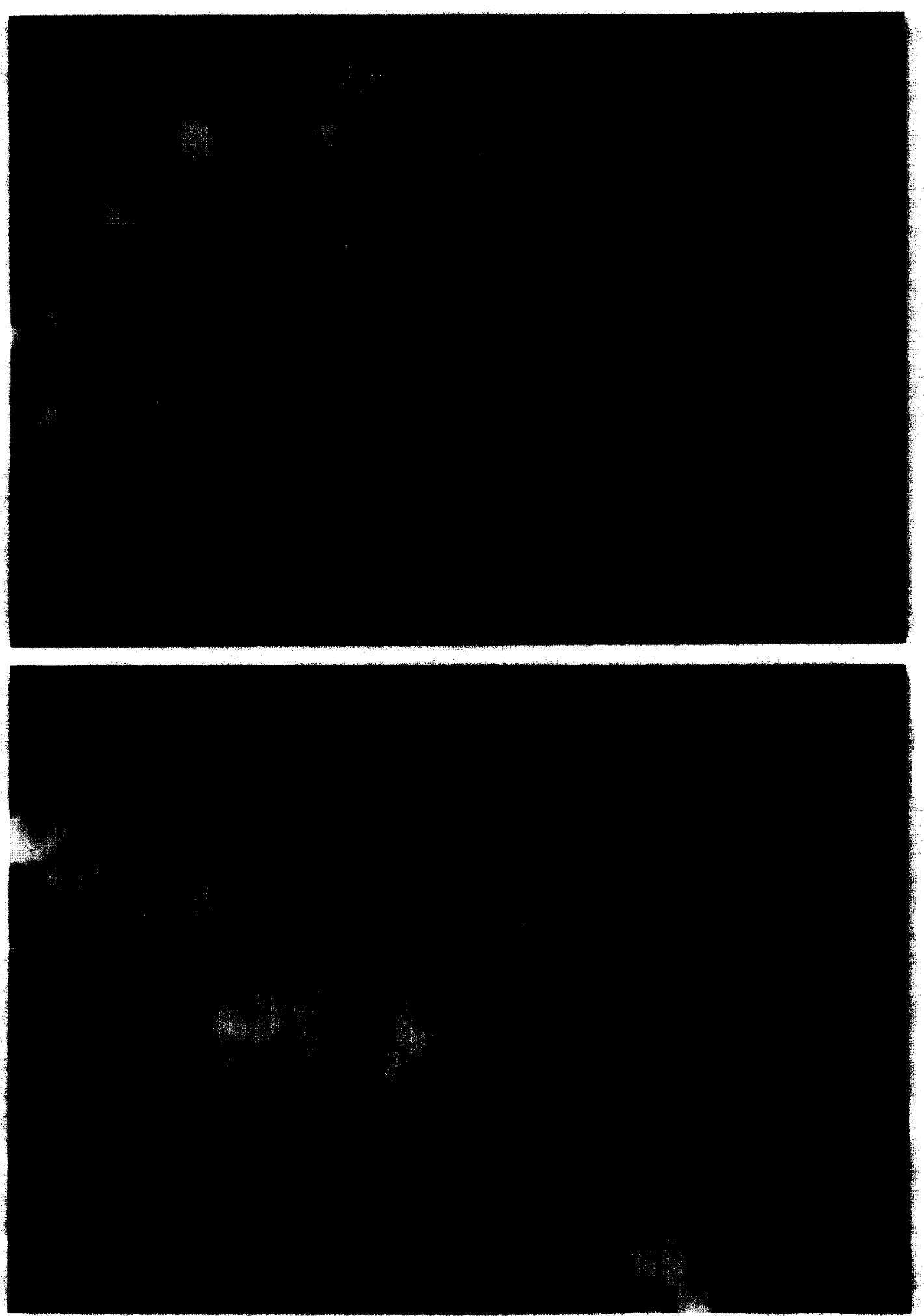

Fig. 1. Cryostat sections of rat cochlea showing GluR $2 / 3$ (A) and GluR 4 (B) immunoreactive staining of spiral ganglion cells. Bar $=25 \mu \mathrm{m}$ 

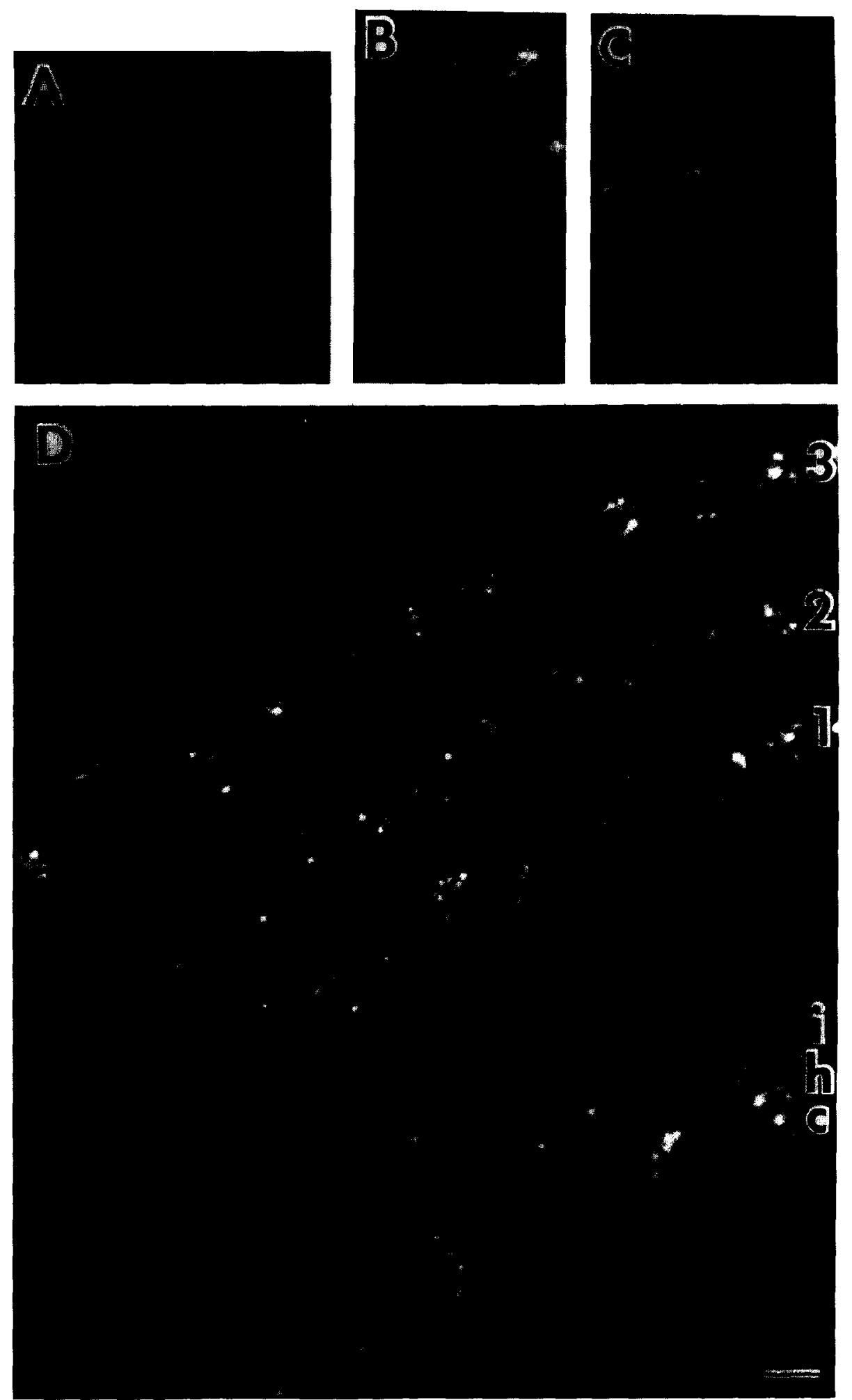

Fig. 2. GluR 4 immunoreactive staining at hair cell bases in the rat cochlea. (A) Surface preparation from the second turn showing immunofluorescent punctate staining at the bases of inner hair cells. (B) Surface preparation from the second turn showing punctate labeling at outer hair cell bases. (C) Cryostat section showing immunofluorescent fiber rising to make a punctate labeling at an outer hair cell base. (D) Laser scanning confocal micrograph, where five focuses (over ten microns) from a surface preparation of the second turn are digitally combined to show many immunofluorescent puncta at inner and outer hair cells bases. Lower tunnel crossing fibers are also seen. ihe $=$ row of inner hair cells. $1,2,3=$ outer hair cell rows, one two, and three. Bar $=10 \mu \mathrm{m}$. 


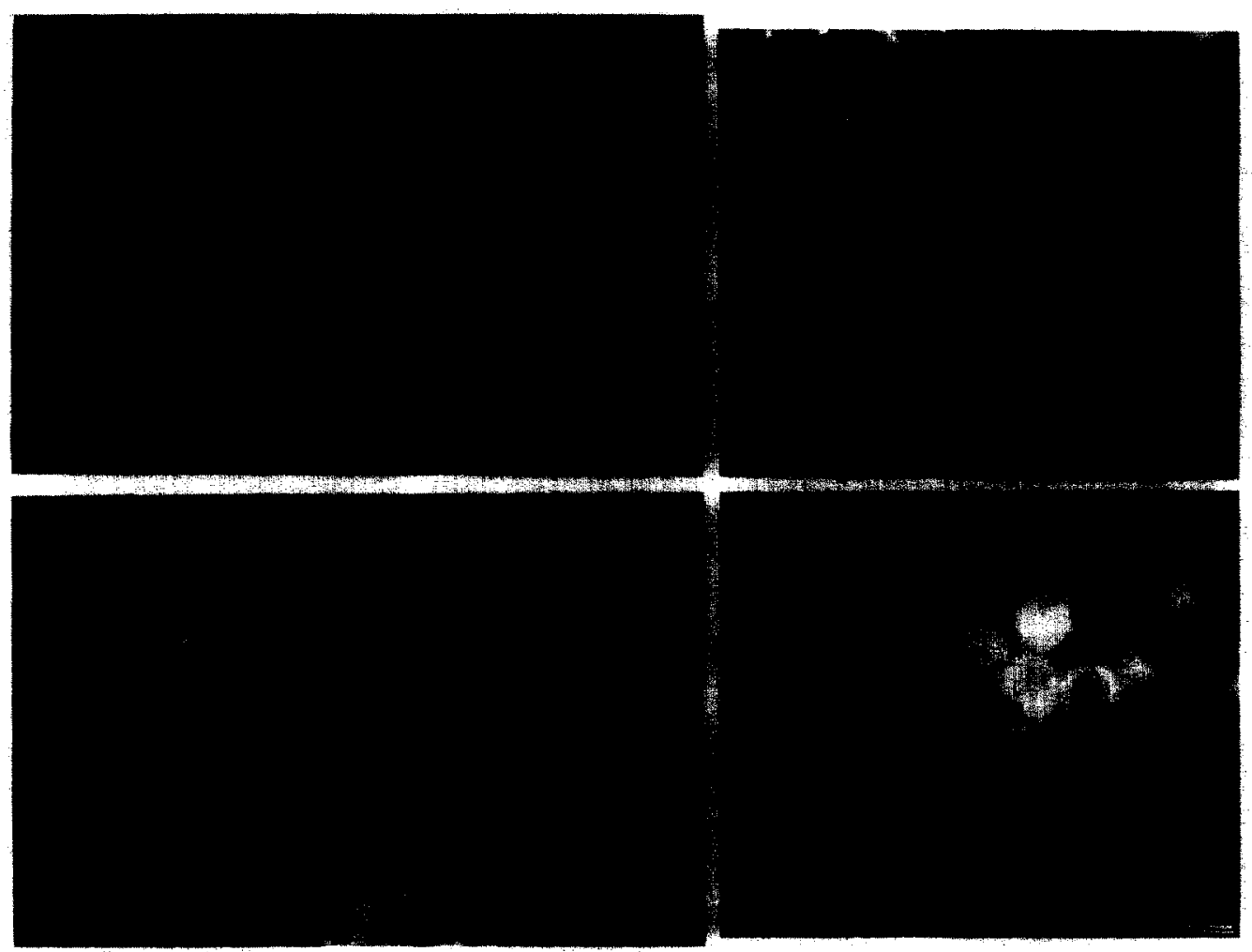

Fig. 3. Photomicrographs showing co-labeling of GluR $2 / 3$ (B) and the $200 \mathrm{kD}$ neurofilament protein (A) in spiral ganglion cells from the same cryostat section through the second turn of the rat cochlea, and co-labeling of GluR 4 (D) and the $200 \mathrm{kD}$ neurofilament protein $(\mathrm{C})$ from another cryostat section through the second turn of the cochlea of the same animal. Cells that are co-labeled for neurofilament and GluR are shown with filled arrowheads. One example of a neurofilament IR cell that was not GluR (GluR 4) immunopositive is shown with an unfilled arrowhead (C and D). $200 \mathrm{kD}$ immunoreactivity is seen in both type II and a few type I spiralganglion cells. Bar $=20 \mu \mathrm{m}$.

It is intriguing that GluR $2 / 3$ immunoreactive staining is not seen in the synaptic region, despite its presence in spiral ganglion cells, and that it produces a band in western blots of organ of Corti surface preparations. GluR 2/3 expression in spiral ganglion cells has also been shown by in situ hybridization (Ryan et
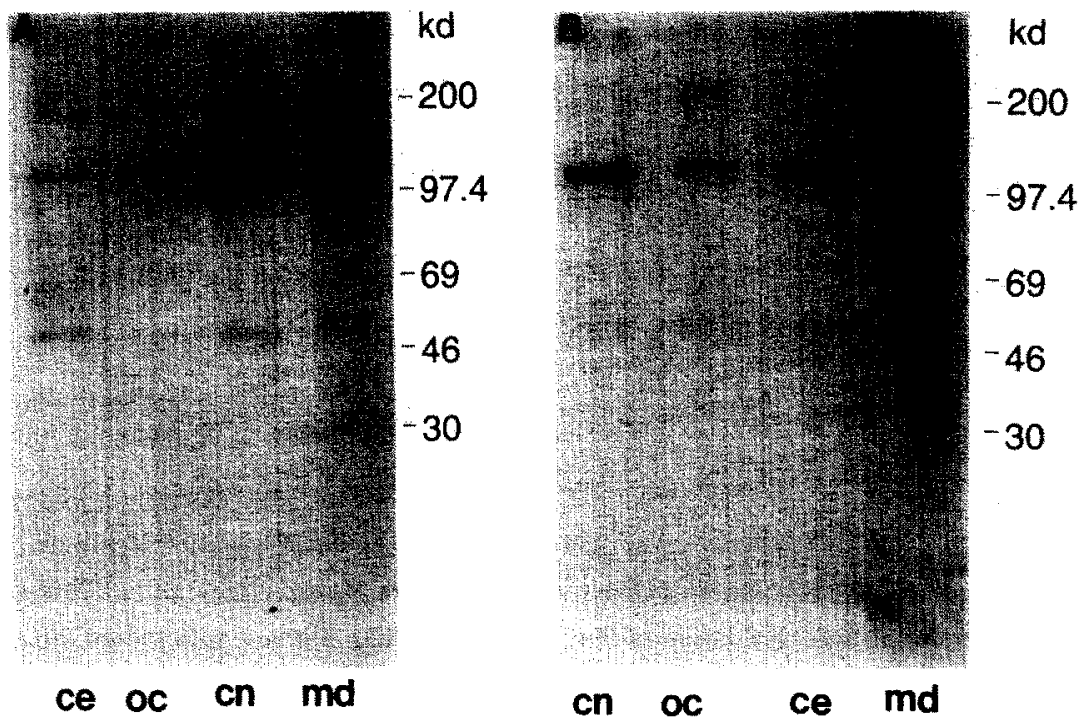

Fig. 4. Western blot analysis of GluR $2 / 3$ (A) and GluR 4 (B) binding to organ of Corti (oc), modiolus (md), cochlear nucleus (cn), and cerebellum (ce). The heaviest bands are for $100 \mathrm{kD}$ (the weight for GluR) and these bands are seen in all tissues. The band for GluR $2 / 3$ (A) in organ of Corti $(o c)$ is light. 
al., 1991; Safieddine and Eybalin, 1992, Niedzielski and Wenthold, 1993). This could suggest that GluR 2/3 is modified before or as it is placed in the hair cell-auditory nerve synapse, such that it loses antigenicity or that it is sequestered in such a way as to be less antigenic or more sensitive to fixation. Further studies will be necessary to elucidate the different components of all excitatory amino receptors in the cochlea, and their functional implications.

\section{Acknowledgements}

We would like to thank Dr. Robert Wenthold for his kind gift of antibodies and Mrs. Kate Koorhan for expert secretarial assistance. This work was supported by NIDCD grants DC00383 and DC00078.

\section{References}

Altschuler, R.A., Kachar, B., Rubio, J.A., Parakkal, M.H. and Fex, J. (1985) Immunocytochemical localization of choline acetyl-transferase-Jike immunoreactivity in the guinea pig cochlea. Brain Res. $33 \% .111$.

Altschuler, R.A., Sheridan, C.E., Horn, J.W. and Wenthold, R.J. (1989) Immunocytochemical localization of glutamate immunoreactivity in the guinea pig cochlea. Hear. Res. $42,167174$.

Berglund. A.M. and Ryugo, D.K. (1986) A monoclonal antibody labels type If neurones of the spiral ganglion. Brain Res. 383 , $328-332$

Berglund, A.M. and Ryugo, D.K. (1991) Neurofilament antibodies and spiral galglion neurons of the mammatian cochlea. J. Comp. Neurol. 3(36, 393-408.

Bledsoe, S.C., Bobbin, R.P. and Puel, J.L. (1988) Neurotransmission in the inner ear. In: A.F. Jahn and J.R. Santos-Sacchi (Eds.), Physiology of the Ear. Raven Press. New York, New York. pp. $385-406$.

Bledsoe, S.C., Bobbin, R.P. and Chihal, D.M. (1981) Technique for studying sound-induced release of endogenous amino acids from the guinea pig cochlea. Abstr. Assoc. Kes. Otolaryngol. pp. 24.

Bobbin, R.P. and Thompson, M.H. (1978) Effects of putative transmitters on afferent cochlea transmission. Ann. Otol, Rhinol. Larvngol, 87, 185-190.

Bobbin. R.P. and Thompson. M.H. (1978) Glutamate stimulates cochleat afferent nerve fibers. Fed. Proc. 37, pp. 613.

Bobbin. R.P. (1979) Glutamate and aspartate mimic the afferent transmitter in the cochlea. Exp. Brain Res. 34, 389-393.

Bobbin. R.P. Bledsoe, S.C. and Chihal, D.M. (1981) Effect of various excitatory amino acid antagonists on guinea pig cochlea potentials. Abstr. Assoc. Res. Otolaryngol pp. 27.

Bobbin, R.P. and Ceasar, G. (1987) Kynurenic acid and gamma-Dglutamylaminomethylsulfonic acid suppresses the compound action potential of the auditory nerve. Hear. Res. 25, 77- 81 .

Boulter, I., Hollman. M. O'Shea-Greenfield, A. Hartley, M., Denris. E. Maron, C. and Heinemann, S. (1990) Molecular cloning and functional expression of glutamate receptor subunit genes. Science 249.1033-1037.

Comis, S. and Leng, G. (1979) Action of putative neurotransmitters in the guinea pig cochlea. Exp. Brain Res. 36. 119-128.

Dau, J. and Wenthold, R.J. (1989) Immunocytochemical localization of neurofilament subunits in the spiral ganglion of normal and neomycin-treated guinea pigs. Hear. Res. 42, 753-264.
Doi, K.. Yokotani, N., Hunter, C., Wada, K. and Wenthold, R.J. (1992) DNA amplification of subunits of the AMPA selective glutamate receptor family of the rat and guinta pig cochlea. Abstr. Assoc. Res. Otolaryngol. pp. 19.

Drescher, D.G. and Drescher, M.I. (1985) HPLC analysis of presumptive neurotransmitters in perilymph. In: D.G. Drescher (Ed.) Auditory Biochemistry, Chatrles ( Thomas, Springfield, IL. pp). $50-67$.

Eybalin. M. and Pujol, R. (1983) A radioatutographic study of $\left[{ }^{3} \mathrm{H}\right] \mathrm{L}$ glutamate and $\left[{ }^{3} \mathrm{H}\right] \mathrm{L}$-glutamine uptake in the guinet pig cochlea. Neuroscience $9.863-872$.

Eybalin. M. and Altschuler. R.A. (1690) Immunoclectron microscopic kocalization of neurotransmitters in the cochleat. J. Flectron Microsc. Tech. 15, 2019-224.

Eybalin. M. (1993) Neurotransmitters and neuromodulators of the mammalian cochleat. Physiol. Rev. 73. 309-73.

Fex. J. and Alschuler. R.A. (1986) Neurotransmitler-related immunucytochemistry of the organ of (orti. Hear. Res. 22. 249-264.

Godfrey, D.A.. Carter, J.A. Berger, S.J. and Matshinsky. F,M. (1976) Levels of putative transmitter amino atcids in the guinca pig cochleal. J. Histochem. (ytochem. 2t. tox-472.

Gulley, R.L.. Fex. J. and Wenthold. R.J. (1979) Untake of putative neturotransmitters in the argan of Corti. Acta Otoluryngol. (Stockh) $88,177-182$.

Hollmann, M., Hartley, M. and Heinemann. S. (199) Ca permeability of KA-AMPA-gated glutamate receptor channels depends on subunit composition. Science 252.851-853.

Hollman. M. OShea-Greenfield A., Rogers S.W. and Heinemann. $s$ (1989) Cloning by fumciomal expression of a member of the glutamate receptor family. Nature $3+2.643-8$.

Janssen. R.. Schweityer, L. and Jensen, K.F. (1991) Glutamate ne'tlrotoxicity in the developing rat cochlea: physiological and motphological approaches. Brain Res. 552. $255-264$.

Jenison, G.L. and Bobbin, R.P. (1985) Quisqualate excites spiral ganglion neurons of guinea pig. Hear. Res. 20, 261-265.

Jenison, G.L... Winbery, S. and Bobhin. R.P. (1986) Comparative actions of quisqualate and $\mathrm{N}$-methyl-1)-ispartame, excitatory amino acid agonists, on guinca pig cochlea. Comp. Biochem. Physiol. 84. 385-389.

Juiz. J.M.. Rueda. J. Merchan, J. and Sala. M.I. (1989) The effects of kainic acid on the cochlea ganglion of the rat. Hear. Res, 4), $6.5-74$.

Keinanen, K., Wisden, W. Sommer, B., Werner, P., Herb, A. Verdoom, T.A., Sakmann. P. and Sceburg, P.1I. (1990) A family of AMPA-selective glutamate receptors. Science 249, 556-560).

Klinke. R. and Oertel. W. (1977) Amino-acids - putative afferent transminter in the cochlea? Exp. Brain Res 30.145-14x.

Kusakari. J. Arakawa, E.. Ohyama, K., Rokuge, M and Inamura, N. (1984) Effect of kainic acid upon NI latency. Laryngescope 9.4. $1365-1369$.

Littman. T, Bobbin. R.P. Fallon M and Puel J.L. (1989) The quinoxalinediones DNOX, CNOX and two related congenes supress cell-to-auditory nerve transmission. Ilear. Res. 41, 45-54.

Nakagawa, T. Komune, S. Uemura, T. and Akaike, N. (1991) Excitatory amino acid response in isolated spiral ginglion cells of guinea pig cochlea, J. Neurophysiol. 65. 715-723.

Niedzielski. A.S. and Wenthold, R.J. (1993) Glutamate receptor expression in the cochlea determined by in silu hybridization. Abstr. Assoc. Res, Otolaryngol. pp. 41.

Petralia, R.S. and Wenthold. R.J. (1992) Light and electron immunocytochemical focalization of AMPA selective glutamate receptors in the rat brain. J. Comp. Neurol. 318. 329)-354.

Puel. J.L.. Bobbin. R.P and Fallon M. (1989) Supression of auditory nerve activity in the guinea pig cochlea by 1 (p-bromobenzoyl)piperazine-2,3-dicarboxylic acod. Brain Res. $487,9-15$.

Puel, J.L., Pujo, R. Ladrech, S. and Lybalin, M. (1991) amamino-3hydroxy-5-methyl-t-isoxazole propionic acid electrophysiological 
and neurotoxic effects in the guinea pig cochlea. Neuroscience $45,63-72$.

Pujol, M., Lenoir, M., Robertson, D., Eybalin, M. and Johnstone, B.M. (1985) Kainic acid selectively alters auditory dendrites connected with cochlea inner hair cells. Hear. Res. 18, 145-152.

Romand, R., Hafidi, A. and Despres, G. (1988) Immunocytochemical localization of neurofilament protein subunits in the spiral ganglion of the adult rat. Brain Res. 462, 167-173.

Ryan, A.F. and Schwartz, I.R. (1984) Preferential glutamine uptake by cochlea hair cells: Implications for the afferent cochlea transmitter. Brain Res. 290, 376-379.

Ryan, A.F., Brumm, D. and Kraft, M. (1991) Occurrence and distribution of non-NMDA glutamate receptor mRNA in the cochlea. Neuroreport 2, 643-646.

Ryan, A.F., Housley, G.D. and Harris, J.P. (1993) Isolation of gene sequences from inner ear using PCR and cDNA library screening. Abst. Assoc. Res. Otolaryngol. 16,88.
Safieddine, S. and Eybalin, M. (1992) Co-expression of NMDA and AMPA/kainate receptor mRNA in cochlea neurons. Neuroreport 3, 1145-1148.

Schwartz, I.R. and Ryan, A.F. (1986) Uptake of amino acids in the gerbil cochlea. In: R.A. Altschuler, D.W. Hoffman and R.P. Bobbin (Eds.), Neurobiology of Hearing; The Cochlea. Raven Press, New York, New York, pp. 173-190.

Wenthold, R.J., Yohotani, N., Doi, K., and Wada K. (1992) Immunochemical characterization of the non-NMDA glutamate receptor using subunit specific antibodies. Evidence for a hetero-oligomeric structure in the rat brain. J. Biol. Chem. 267, 501-507.

Wenthold, R.J., Hunter C., Wada K., And Dechesne C.J. (1990) Antibodies to a C-terminal peptide of the rat brain glutamate receptor subunit, GluR-A, recognize a subpopulation of AMPA binding sites but not kainate sites. FEBS Lett 276, 147-150. 